\title{
Müzik Öğretmenlerinin Piyano ile Eşliğin Önemi ve Gerekliliğine Yönelik Görüşlerinin İncelenmesi
}

\section{Examination of Music Teachers' Views on the Importance and Necessity of Accompaniment with Piano}

\section{Mehmet Kayhan Kurtuldu}

Prof. Dr., Trabzon Üniversitesi, Fatih Eğitim Fakültesi, Müzik Öğretmenliği Anabilim Dalı email: kayhankurtuldu@gmail.com DORCID ID: https://orcid.org/0000-0003-0064-9144

\footnotetext{
iThenticate" Bu makale bilimsel etik ve kurallara uygun hazırlanmış ve intihal incelemesinden geçirilmiştir. 22/01/2021 tarihli Trabzon Üniversitesi Sosyal ve Beşeri Bilimler Araştırma ve Yayın Etik Kurulu onayı alınmıştır.

Atıf (APA 7)/To cite this article

Kurtuldu, M. K. (2021). Müzik öğretmenlerinin piyano ile eşliğin önemi ve gerekliliğine yönelik görüşlerinin incelenmesi. Atatürk Üniversitesi Güzel Sanatlar Enstitüsü Dergisi, 27(47), 322-328. https://doi.org/10.35247/ataunigsed.925477
}

Makale Gönderim Tarihi/Received: 22/04/2021

Makale Kabul Tarihi/Accepted: 21/07/2021

Makale Yayın Tarihi/Published: 28/10/2021

Research Article / Araştırma Makalesi

$\ddot{O} z$

Bu çalışmada aktif olarak görev yapan müzik öğretmenlerinin, müzik derslerinde piyano ile eşliğin önemi ve gerekliliğine yönelik görüşleri incelenmiștir. Çalıșma kapsamında tarama modelinden faydalanılmış ve müzik öğretmenlerine Kurtuldu (2016) tarafından geliştirilmiş olan "Piyano ile Eşliğe İlişkin Görüş Anketi” uygulanmıştır. 32 maddeden oluşan anket yardımıyla müzik öğretmenlerinin derslerde piyano ile eşlik kavramına yönelik görüşleri elde edilmiş ve bu görüşler, anket öncesinde sorular çeşitli değişkenler (cinsiyet, kıdem, okul türü vb.) ile karşılaştırılmıștır. Elde edilen veriler çeşitli istatistik işlemlere tabi tutulmuştur. Tanımlayıcı istatistik işlemler (frekans, ortalama vb.) yanında karşılaştırmalı ölçümlerden de (U testi, $\mathrm{H}$ testi) faydalanılmıştır. Sonuçlar incelendiğinde müzik öğretmenlerinin derslerde piyano ile eşlik yapmanın oldukça önemli bir kavram olduğu fikrinde birleștikleri anlaşılmaktadır.

Anahtar kelimeler: Piyano Eşlik, Müzik Öğretmeni, Önem, Gereklilik

\begin{abstract}
In this study, the views of the active music teachers about the importance and necessity of accompaniment with piano in music lessons were examined. Within the scope of the study, the survey model was used and the "Opinion Questionnaire on Accompaniment with Piano" developed by Kurtuldu (2016) was applied to the music teachers. With the help of the questionnaire consisting of 32 items, the opinions of music teachers about the concept of piano and accompaniment in lessons were obtained and these opinions were compared with various variables (gender, seniority, school type, etc.) before the questionnaire. The data obtained were subjected to various statistical processes. In addition to descriptive statistical processes (frequency, average, etc.), comparative measurements (t-test, $\mathrm{H}$ test) were also used. When the results are examined, it is understood that music teachers agree on the idea that accompaniment with piano in lessons is a very important concept.
\end{abstract}

Keywords: Piano Accompaniment, Music Teacher, Importance, Necessity

\section{Giriş}

Piyano gerek yapısı, gerek sunduğu olanaklar, gerek literatürü ve gerekse eğitimi açısından oturmuş gelişim aşamaları ve kapsayıcı yönü ile hiçbir çalgının kendisiyle yarışamayacağı bir ayrıcalıktadır. Bu ayrıcalık, hem solo, hem eşlik, hem de solo ile eşliği bir arada yürütebilme kapasitesi ile pek çok etkinliği de tek başına yürütebilecek yetkinliği piyanoya kazandırmaktadır. Fakat piyanonun eğitim öğretim kurumlarında öne çıkan ve belki de sıkça kullanıldığı ortamlar aslında eşlik çalgısı olarak kullanıldığı ortamlardır. Dolayısıyla piyanonun eşlik ile olan ilişkisini ve okul ortamlarındaki gerekliliğini işlemek önemli bir kavram olarak karşımıza çıkar.

Eşlik kelimesi için insan sesi veya bir çalgı için yazılmış ve bunlar ile seslendirilen, hem asıl sesi (melodiyi) destekleyen, hem de kendine özgü yapısı içerisinde akan tamamlayıcı müzikal yapı, müzikal ses veya sesler bütünü ifadesi kullanılabilir (Kaptanoğlu ve Çanakçı, 2015). Bu sesler bütününü gündelik hayat pratiğine uygun ve kendi yapısı ile müziğin melodi, armoni ve ritim gibi tüm öğelerini yaşayan, çok sesliliği tümüyle seslendirebileceğimiz ve eşlik amaçlı kullanılabilecek olup, dünyada da en yaygın kabul görmüş çalgılardan biri piyanodur (Sökmen, 2018).

Piyanonun solo çalgı özelliği taşıması, armoni oluşturma kabiliyeti ve bütün çalgılarla olan tını birlikteliği gibi hususlar, en küçük müzik topluluklarından büyük orkestralara kadar müzik icra edilen her yerde piyanoyu başta gelen eşlik çalgılarından biri olarak karşımıza çıkartmaktadır (Pala ve diğerleri, 2016).

Üzerinde seslerin hazır olması, geniş bir ses aralığına sahip olması ve polifonik karaktere sahip olması, ses şiddetinin yeterliliği, artikülasyon genişliği ve fiziksel yapısı sebebiyle piyano, kendine yeten önemli bir eğitim ve eşlik çalgısıdır. Bu durum piyanoyu müzik öğretmenleri ve adayları için alan bilgisi destekleyen, gerek meslek hayatı, gerekse çalg1 ve ses eğitimi sürecinde de vazgeçilmez kılan işlevsel bir çalgı haline getirmektedir. 
Dolayısıyla bu işlev piyano ile bireysel performans sergileme ve piyano ile eşlik çalma kullanıma dönüşebilir (Özelma ve Çiftçi, 2013; Bayırlı ve Yıldız, 2021).

Müzik eğitimi verilen kurumlarda piyano, bireysel ses eğitimi, koro, armoni, müziksel işitme okuma yazma gibi derslerde aktif olarak kullanılabildiği ve armonik çoksesliliği sağlayabildiği için eşlik çalgısı olarak da önemli bir role sahiptir (Altungül, 2019; Okan ve Mohan Kömürcü, 2020). Piyano, bir orkestranın seslendirebileceği tüm ses alanını kapsadığı ve tek bir kişinin parmakları yardımıyla yerine göre tek başına bir orkestra olabildiği ve bu çeşitliliğin getirdiği birliği bünyesinde barındırabildiği için tüm bu armonik yapıları yeniden duyurabilme ve diğer tüm çalgılara da eşlik edebilme kapasitesine sahiptir (Okan ve Mohan Kömürcü, 2020; Gün ve Öztürk, 2018). Piyanoyu farklı kılan ve eşlik çalgısı olarak da diğer tüm çalgılardan ayıran özelliklerin en etkin ve faydalı olduğu unsurlar, esasen ders ortamları, dersi pekiştirecek uygulamalar ve özellikle de şarkı öğretimi ve çalıştırılması sürecindeki katkılardır. Bir eşlik çalgısı olarak piyano, müzik dersi ortamlarının en önemli çalgısı ve yardımcı bir ders aracı konumundadir.

Gerek piyano tekniği ve kapsamı ile uyumu ve önemli bir yönü olması açısından, gerekse uygulama alanı itibariyle eğitim öğretim faaliyetlerinin bir yönü ve kalitesini artırıcı bir unsuru olması açısından piyano ile eşlik kavramı, müzik eğitimi sürecinin de vazgeçilmez bir yapıtaşıdır. Piyanonun kesin ve etkin rolünün bu yapıtaşı olma rolünde etkisinin büyük olduğu düşünülse de eşlik kavramının bizatihi kendisinin müziğin ana unsurlarından biri olduğu da gerçektir. Eşlik şu veya bu şekilde hemen her toplu çalışmanın sürükleyici bir unsurudur. Bu sebeple eşliksiz bir müzik dersinin düşünülmesi, müzik dersinin kalitesine yönelik önemli bir desteği ortadan kaldırmak olarak görülebilir (Kurtuldu, 2018).

Ders sürecinde tüm müzik ö̆gretmenlerinin klavyeli çalgı grubundaki (org, piyano vb.) çalgılar ile solo seslendirme yapması ve bu seslendirmeleri yapacağı eşlikler ile zenginleştirerek etkin kullanım sağlaması mümkündür. Bunun yanında iyi bir müzik öğretmeninin, öğreteceği bir şarkıyı armonik açıdan analiz edebilmesi, o şarkıya ya da başka şarkılara eşlik yazabilmesi ve bu eşlikleri seslendirmesi, aldığı çeşitli derslerde öğretiliyor olduğu için gereklidir (Kardeş, Akbulut-Demirci, 2019). İyi bir müzik öğretmeninin yukarıda bahsedilen eşlikleri yazması, yazmak için gerekli analizleri, tespitleri yapması ve bunu doğru olarak seslendirmesi için birikimin sağlaması gereklidir. Hem teknik, hem müzikal beceriler ile armoni ve çözümleme gibi işlevsel beceriler de bu birikim için önemlidir.

Piyano çalarken herhangi bir eseri icra edebilmek, teknik becerilerin doğru ve kalıcı bir şekilde kazanılmış olmasına bağlıdır (Kalkanoğlu, 2020). Müzik eğitimi alan öğretmen adaylarının piyano ile eşlik yapması, sadece piyano eğitimine ve bu derslerdeki yöntem ve tekniklere bağlı değildir. Süreç içerisinde bu eğitimi destekleyecek ve bilhassa yazılı bir eşlik olmadığı durumlarda deşifre olarak eşlik yapmayı sağlayacak müzik teorisi bilgileri, çok seslendirme teknikleri, armoni ve form bilgisi, kontrpuan gibi teorik altyapıya da ihtiyaç vardır. (Babacan ve Gökbudak, 2011; Özdemir, 2017). Müzik öğretmenlerinin piyano ile eşlik kavramına ihtiyaç duyduğu ortamların ders ortamları olduğu yukarıda bahsedilmiştir. Fakat ders ortamlarında en çok işlev, özellikle şarkı öğretimi ve şarkı söyletme uygulaması ya da tören hazırlıkları gibi süreçlerde kendini göstermektedir.

Şarkı öğretimi esnasında piyano ile eşlik yapmak, öğrencilerin zihninde eserin temposunu, nüansını, şarkının duygusunu ve ana fikrini anlamasına yardımcı olacağı açıktır (Çevik ve Güven, 2011). Bu öğretim süreci sırasında piyano eşliği, şarkıdaki duyguyu, düşünceyi ve öğretilmek istenilen temayı da desteklemeklerken, farklı türlerdeki şarkı çalışmalarında da doyum sağlamaktadır. Şarkılarda geçen duygu, düşünce, tasarı ve izlenimleri pekiştirmek gibi istendik/beklendik etkileri sağlamak, armonik kurallara uygun ve şarkı ile bütünleşen piyano eşlikleri ile daha mümkün olabilmektedir (Özalp ve Özdemir, 2015).

Piyano ile eşlik literatürü incelendiğinde, eşliğin tanımı ve yapısı, iyi eşlik için gerekli olan hususlar, piyano eşliğin okul ortamındaki etkisi ve gücü üzerinde durulduğu görülmektedir. Bu konuda literatürün özellikle öğretmenlere ve öğretmen adaylarına görev yüklediği, iyi yetişmiş ö̆gretmen tanımıyla bu gruba önemli atıflar yaptığı da izlenmektedir. Dolayısıyla ve özellikle aktif görev yapan müzik öğretmenlerinin piyano ile eşlik kavramına yönelik görüşleri, farkındalıkları ve gerekliliği hususundaki bakış açıları özen kazanmaktadır. Öğretmenlerin gerek kendi donanımları, gerekse okul ve derslik olanakları kapsamında ne düşündüğünün incelenmesi ve dile getirilmesi, durumu ortaya çıkartmak açısından da önem kazanmaktadır.

\section{Yöntem}

Bu çalışmada aktif olarak görev yapan müzik öğretmenlerinin, müzik derslerinde piyano ile eşliğin önemi ve gerekliliğine yönelik görüşlerinin incelenmesi amaçlanmıştır.

Yapılan çalışmada tarama modelinden ve bu kapsamda da anket tekniğinden faydalanılmıştır. Karakaya (2014), tarama araştırmalarını görece geniş gruplarla yürütülen ve bu grupların bir konu ya da olay ile ilgili görüşlerinin veya tutumlarının elde edildiği ve ilgili oldu veya olayı betimleyen araştırmalar olarak tanımlarken (s. 59), Sevinç (2017), tarama modelini iki farklı başlıkta değerlendirmiş, bu çalışmaya da uygun gelen bir alt başlıkta modeli ilgili bazı değişkenler ve bu değişkenlerin arasındaki ilişkiyi belirleyen tarama çalışmaları olarak açıklamıştır (s. 269). Armağan (1983) ise anket tekniğini belirli bir konu kapsamında yazılmış varsayımlar veya sorulara bağlı, 
belirlenmiş bir örneklem ya da gruptaki kişilere sorulan sorular ile yürütülen sistemli bir veri toplama tekniği biçiminde tanımlamıştır (aktarıldığı gibi Balcı, 2009, s. 146).

\section{1. Çalışma Grubu}

Araştırmanın çalışma grubunu milli eğitim bakanlığına bağlı okullarda görev yapan müzik öğretmenleri oluşturmaktadır. Çeşitli ortaokul ve lise türlerine göre müzik dersi yürüten öğretmenlerin görüşleri anket yoluyla toplanmıştır. Okul türü veya bölge ayrımı yapmaksızın online olarak öğretmenlere ulaşıldığı ve bu kapsamda tüm müzik öğretmeni evrenini temsil edecek homojenlikte örneklem temsil türü oluşmadığı için, veri toplanan grup çalışma grubu olarak isimlendirilmiştir. Çalışma grubu toplamda 556 müzik öğretmeninden oluşmaktadır.

Tablo 1

Çalışma Grubu Demografik Veriler

\begin{tabular}{lcc}
\hline Cinsiyet & f & \% \\
\hline Kadın & 388 & 69.8 \\
Erkek & 168 & 30.2 \\
\hline Kıdem & f & $\mathbf{\%}$ \\
\hline $1-5$ yıl & 50 & 9 \\
$6-10$ y1l & 86 & 15.5 \\
$11-15$ yıl & 96 & 17.3 \\
$16-20$ y1l & 104 & 18.7 \\
21 y1l ve üzeri & 220 & 39.6 \\
\hline Müzik Dersliği & f & $\mathbf{\%}$ \\
\hline Var & 388 & 69.8 \\
Yok & 168 & 30.2 \\
\hline Derslikte Piyano & f & $\mathbf{\%}$ \\
\hline Var & 356 & 64 \\
Yok & 200 & 36 \\
\hline
\end{tabular}

\subsection{Verilerin Toplanması}

Araştırmanın verilerinin toplanmasında ilk olarak piyano ile eşlik literatürü taranmış ve konu kapsamındaki çalışmalar incelenmiştir. Kapsam dahilinde müzik öğretmenlerine uygulamak üzere Kurtuldu (2016) tarafindan geliştirilmiş olan "Piyano ile Eşliğe İlişkin Görüş Anketi" kullanılmıştır. Anket 32 maddeden oluşmaktadır ve piyano ile eşliğin derslerde, etkinliklerde ve müzik öğretmeni yetiştirme sürecindeki önemi ve gerekliliği irdelenmektedir. Anket maddeleri öncesinde cinsiyet, mesleki kıdem, çalışılan okul türü, mezun olunan program, müzik sınıfı ve ders ortamında piyano olup olmadığı gibi değişkenler sorulmuştur. 32 maddeden oluşan anket için 5 seçenekli likert tipinde ve "tamamen katılıyorum”, "katılıyorum”, "kısmen katılıyorum”, "çok az katılıyorum”, "hiç katılmıyorum" biçiminde cevap seçenekleri tercih edilmiştir. Kullanılan anketin geliştirilme aşamasında güvenirlik katsayısı Alpha 0.96 olarak bulunmuştur. Anketin öz değeri 1'den büyük 3 faktör altında toplandığ1, toplam varyansı açıklama oranının da \%58.10 düzeyinde gerçekleştiği gözlenmiştir. Anket istatistik ölçümler neticesinde üç alt başlıktan oluşan bir yapı ile sunulmuştur. Anket geliştirme çalışmasında ortaya çıkan alt başlıklar Kurtuldu (2016) tarafından şu şekilde sunulmuştur;

1- Öğretmenlik mesleğine yönelik önem ve gereklilik (Öğretmenlik mesleği ÖM)

2- Okul etkinlikleri ve derslerde kullanımına yönelik önem ve gereklilik (Okul etkinlikleri OE)

3- Piyano eşlik eğitimi ve becerisine yönelik önem ve gereklilik (Eşlik eğitimi EE)

\subsection{Verilerin Çözümlenmesi}

Verilerin çözümlenmesi sürecinde ilk olarak toplanan veriler için güvenirlik ölçümü yapılmış ve bu ölçümde Alpha katsayısı 0.91 olarak bulunmuştur. Yüksek düzeyli güvenirlik sonucu neticesinde istatistik işlemlere devam edilmiş ve verilerin norma dağılım varsayımını karşılayıp karşılamadığı sorgulanmıştır. Normallik incelemesinde betimsel yöntemlerin de diğer yöntemlerle birlikte kullanılması önerilmektedir (McKillup, 2012; Abbott, 2011 ve Gnanadesikan, 1997'den aktarıldığı gibi Demir ve diğerleri, 2016) ve bu tip ölçümlerde gözlem sayısının 29'dan (Ak, 2009, s. 10) veya 30'dan (Can, 2017, s. 89) büyük olması durumu Kolmogorov-Smirnov testi için uygun bir durumdur. $\mathrm{Bu}$ sebeple normallik varsayımında basıklık çarpıklık katsayıları ve Komogorov Smirnov testi marifetiyle birden fazla ölçüm kullanılmıştır.

Tablo 2

Normallik Dă̆ılımına Yönelik Veriler

\begin{tabular}{lcccccc}
\hline & \multicolumn{2}{c}{ Basıklık } & \multicolumn{2}{c}{ Çarpıklık } & \multicolumn{2}{c}{ Kolmogorov-Smirnov } \\
\cline { 2 - 7 } & Ölçüm & SS & Ölçüm & SS & Z & p \\
\hline Toplam & -.848 & .104 & .595 & .207 & 1.99 & .001 \\
\hline
\end{tabular}

Basıklık çarpıklık katsayısı için Z değeri hesaplamasında basıklık çarpıklık değerinin kendi standart hatasına bölümü ile yapılacağı, referans aralıklarının da $Z>1.96$ ise .05 manidarlık düzeyinde, $\mathrm{Z}>2.58$ ise .01 manidarlık 
düzeyinde, Z>3.29 ise .001 manidarlık düzeyinde normal dağılım göstermeyeceği ifade edilmektedir (Taşpınar, 2017, s. 33; Bursal, 2017, s. 50). Çokluk ve diğerleri (2014) de Kolmogorov-Smirnov testi için sonucun manidar çıkması durumunda dağılımın normal normal dağılımdan farklı olacağına vurgu yapmışlardır. Bu bilgiler 1şığında bakılırsa basıklık çarpıklık için Z değeri 8.15 ve 2.87 olarak bulunmuş, diğer testte de $\mathrm{p}<.05$ düzeyine göre anlamlı farka rastlanmıştır. Bu durum verilerin normal dağılım varsayımını karşılamadığını, karşılaştırmalar için parametrik olmayan testler uygulanması gerektiğini ortaya çıkarmıştır.

Karşılaştırmalı ölçümler sürecinde parametrik olmayan testlerden faydalanılmıştır. Bu kapsamda iki cevap seçenekli değişkenler için (cinsiyet, müzik dersliği vb.) Mann Whitney U testi, üç ve fazlası cevap seçenekli değişken olan kıdem değişkeni için Kruskal Wallis H testi kullanılmıştır. Bu testler için manidarlık sınırı olan $\mathrm{p}<.05$ düzeyi kabul edilmiştir.

\section{Bulgular}

Bu bölümde bulgular ilk olarak öğretmenlerin verdikleri cevapların ortama puan ölçümleri ile tablolaştırılması ve katılan öğretmenlerin görüşlerinin genel hatlarıyla tespiti biçiminde sunulmuştur. Devamında verilen cevapların çeşitli değişkenlere göre karşılaştırılması yer almaktadır.

Tablo 3

Ankete Verilen Cevapların Dă̆ılımı

\begin{tabular}{|c|c|c|c|c|c|}
\hline MADDELER & 5 & 4 & 3 & 2 & 1 \\
\hline Piyano ile eşlik yapabilmenin bir müzik öğretmeni için gerekli olduğunu düşünüyorum & $\% 83.5$ & $\% 12.6$ & $\% 3.6$ & $\% 0.4$ & --- \\
\hline Piyano eşliğine lisans eğitiminde daha fazla zaman ayrılması gerekt & $\% 87.8$ & $\% 11.2$ & $\% 1.1$ & --- & --- \\
\hline $\begin{array}{l}\text { Bir müzik ögretmeninin piyanoda eşlik yazabilme becerisine de sahip olması gerektiğini } \\
\text { düşünüyorum }\end{array}$ & $\% 74.1$ & $\% 19.8$ & $\% 4.7$ & $\% 1.1$ & $\% 0.4$ \\
\hline Piyano eşliğinde öğretilen konuların daha iyi öğrenileceğine inanıyorum & $\% 65.1$ & $\% 26.6$ & $\% 7.9$ & --- & $\% 0.4$ \\
\hline Lisans eğitiminde firsat buldukça piyano ile eşlik çalışmanın gerekli olduğuna inanıyorum & $\% 77$ & $\% 20.1$ & $\% 2.5$ & --- & $\% 0.4$ \\
\hline Piyano eşliği iyi olan bir öğretmenin özgüveninin de yüksek olacağına inanıyorum & $\% 73.7$ & $\% 15.8$ & $\% 8.6$ & $\% 1.1$ & $\% 0.7$ \\
\hline Lisans eğitiminde piyanoda teknik yerine daha çok eşlik çalışılması gerektiğini düşünüyorum & $\% 50.7$ & $\% 22.7$ & $\% 20.5$ & $\% 2.9$ & $\% 3.2$ \\
\hline Okul şarkılarını sevdirmek için piyano eşliğinin gerekli olduğunu düşünüyorum & $\% 73$ & $\% 20.1$ & $\% 6.1$ & $\% 7$ & --- \\
\hline Piyano eşliği için daha fazla kaynak kitapların olması gerektiğine inanıyorum & $\% 76.3$ & $\% 19.4$ & $\% 4$ & --- & $\% 0.4$ \\
\hline Piyano eşliği ile öğrencilere birlikte çalma-söyleme zevki verilebileceğine inanıyorum & $\% 78.1$ & $\% 20.4$ & $\% 1.4$ & --- & --- \\
\hline İyi bir piyano eşliğinin iyi bir öğretim yöntemi kadar önemli ve etkili olduğuna inanıyorum & $\% 68.6$ & $\% 26.7$ & $\% 4.7$ & --- & --- \\
\hline Derslerde piyano eşliği kullanmanın öğrencileri daha iyi motive edeceğine inanıyorum & $\% 75.5$ & $\% 20.9$ & $\% 3.2$ & $\% 0.4$ & --- \\
\hline Piyano eşliğinin öğrencilerin müzikal gelişimleri üzerinde de etkili olduğunu düşünüyorum & $\% 74.5$ & $\% 21.6$ & $\% 3.6$ & $\% 0.4$ & --- \\
\hline monotonluktan kurtarmak için gerekli olduğu & $\% 69.3$ & $\% 23.1$ & $\% 7.2$ & $\% 0.4$ & --- \\
\hline Piyano ile eşliğin diğer bazı becerilerin gelişiminde de önemli olduğunu düşünüyorum & $\% 52.2$ & $\% 33.1$ & $\% 12.9$ & $\% 1.4$ & $\% 0.4$ \\
\hline Piyano eşlik becerilerinin lisans eğitimi sonrasında da geliştirilebileceğine inanıyorum & $\% 48$ & $\% 36.8$ & $\% 13$ & $\% 1.8$ & $\% 0.4$ \\
\hline Okul şarklarının her zaman piyano eşliği ile öğretilmesi gerektiğini düşünüyorum & $\% 39.2$ & $\% 29.9$ & $\% 25.2$ & $\% 2.5$ & $\% 3.2$ \\
\hline Piyano eşlik becerisine sahip olmayan bir öğretmenin eksik k & $\% 41.5$ & $\% 29.6$ & $\% 20.2$ & $\% 5.4$ & $\% 3.2$ \\
\hline İyi eşlik yazabilmek için iyi düzeyde armoni bilgisi gerektiğine inanıyorum & $\% 48.9$ & $\% 34.5$ & $\% 14.7$ & $\% 1.8$ & --- \\
\hline Hemen her müzik dersinde piyano eşliğinin kullanılması gerektiğine inanıyorum & $\% 24.8$ & $\% 31.7$ & $\% 34.5$ & $\% 2.2$ & $\% 3.2$ \\
\hline Piyano ile eşlik yapabilmenin bir öğretmen için oldukça önemli bir nitelik olduğunu düşünüyorum & $\% 59.7$ & $\% 33.1$ & $\% 6.1$ & --- & $\% 1.1$ \\
\hline Lisans eğitimindeki eşlik dersi içeriğinin gözden geçirilmesi gerektiğini düşünüyorum & $\% 67.6$ & $\% 29.1$ & $\% 2.9$ & $\% 0.4$ & --- \\
\hline Piyano eşliği konusunda öğretmenlerin kendilerini geliştirmesinin önemli olduğuna inar & $\% 71.2$ & $\% 26.3$ & $\% 2.2$ & $\% 0.4$ & --- \\
\hline Teorik konular anlatılırken de piyano eşliğinin gerekli olduğunu düşünüyorum & $\% 44.2$ & $\% 29.9$ & $\% 18.7$ & $\% 5$ & $\% 2.2$ \\
\hline Lisans eğitiminde alınan eşlik eğitiminin yetersiz olduğuna inanıyorum & $\% 65$ & $\% 23.1$ & $\% 10.5$ & $\% 1.4$ & --- \\
\hline Okul şarkılarının piyano eşliği ile daha kolay öğretilebileceğine inanıyorum & $\% 58.7$ & $\% 32.2$ & $\% 7.2$ & $\% 1.1$ & $\% 0.7$ \\
\hline Piyano ile eşliğin etkinliklerin kalitesini arttıracağına inanıyorum & $\% 62.1$ & $\% 32.9$ & $\% 4.0$ & $\% 1.1$ & --- \\
\hline Piyano eşlik becerilerinin yalnızca lisans eğitimi sürecinde kazanılabileceğini düşünüy & $\% 15.1$ & $\% 18.3$ & $\% 39.2$ & $\% 12.2$ & $\% 15.1$ \\
\hline Piyano eşliği iyi olan öğretmenin daha kolay etkinlik hazırlayabileceğine inanıyorum & $\% 44.2$ & $\% 30.6$ & $\% 16.6$ & $\% 2.9$ & $\% 6.1$ \\
\hline İyi eşlik çalmanın iyi piyano çalma ile ilişkili olduğuna inanıyorum & $\% 26.3$ & $\% 33.8$ & $\% 35.3$ & $\% 4$ & $\% 0.7$ \\
\hline Her okulda bir piyano ya da org olması gerektiğine inanıyorum & $\% 69.1$ & $\% 27.3$ & $\% 3.2$ & $\% 0.4$ & --- \\
\hline İyi eşlik yapabilmek için bilgimin ve tekniğimin eksik olduğunu düşünüyorum & $\% 10.8$ & $\% 25.5$ & $\% 32$ & $\% 14.4$ & $\% 17.3$ \\
\hline
\end{tabular}

Tablo incelendiğinde tüm maddelerde olumlu bir eğilim olduğu, öğretmenlerin bir iki madde dişında tamamen katılıyorum (5) ve katılıyorum (4) seçenekleri üzerinde yoğunlaştığı gözlenmiştir. Kısmen yoruma ve kişisel düzeye bağlı bir iki maddede eğilimin orta düzeyli olduğu, kısmen katılıyorum (3) seçeneği üzerinde eğilimler oluştuğu da anlaşılmaktadır. Bilgi ve teknik eksiklik, sadece piyano ile şarkı öğretilmesi gibi seçeneklerde farklı eğilimler olsa da diğer tüm maddelerde oldukça olumlu bir katılım düzeyi kendini göstermektedir. 
Tablo 4

Ankete Verilen Cevapların Dă̆glımı

\begin{tabular}{ccccc}
\hline Başlıklar & Puan Aralıkları & Min. & Max. & Ort. \\
\hline Tüm Anket & $32-160$ & 92 & 160 & 39.81 \\
ÖM & $7-35$ & 16 & 35 & 70 \\
OE & $14-70$ & 37 & 62.48 & 55 \\
EE & $11-55$ & 31 & 46.08 & 55 \\
\hline
\end{tabular}

Tablo 4'te yer alan bilgiler, anketin tümünden alınan puanlar ile üç alt başlığından alınan puanlar olarak gruplanmıştır. Puan aralığı olarak verilen aralıklar da anketin tümü ve alt başlıkların her birinden alınacak en az ve en çok puanın ne kadar olabileceğini göstermektedir. Bu puanlar verilecek cevapların olumsuzdan olumluya doğru artışına da işaret etmektedir. Alınan puan ve ortalama yükseldikçe olumlu eğilim artmaktadır.

Bu açıklamalar 1şı̆ğında puanlar değerlendirilirse, anketin tümü ve alt başlıklarda oldukça olumlu bir görüş bütününün oluştuğu anlaşılmaktadır. Her bir basamakta alınan puanların hiçbiri minimum puanda alt sınıra yaklaşmazken, maksimum düzeyde alınan en üst puanlar puan aralığının da en üst puanına denk gelmektedir. Tüm ankette oluşan 139,81 düzeyindeki ortalama dağılımı ve diğer başlıklardaki ortalama dağılımı, puan aralığının üst sınırına yakın düzeyde gerçekleşmiştir. Buna göre öğretmenlerin piyano ile eşlik konusunda ve ayrı ayrı diğer üç alt başlıkta da olumlu bir eğilim gösterdiği anlaşılmaktadır.

Tablo 5

Cinsiyet Değişkenine Yönelik Karşılaştırma

\begin{tabular}{ccccccc}
\hline Cinsiyet & Sira Ort. & Sira Top. & SS & U & Z & \multirow{2}{*}{0} \\
\hline Kadın & 280.80 & 108950 & \multirow{2}{*}{0.451700} & \multirow{2}{*}{608} \\
Erkek & 273.19 & 45896 & & & \\
\hline
\end{tabular}

Tablo 5 incelendiğinde ankete verilen cevapların cinsiyet değişkenine göre karşılaştırılmasında $p<.05$ düzeyine göre anlamlı bir farka rastlanmamıştır. Eşliğin önemi ve gerekliliğine yönelik ankete verilen cevaplar, cinsiyet değişkeninden etkilenmemiştir.

Tablo 6

Okulda Müzik Dersliği Değişkenine Yönelik Karşılaştırma

\begin{tabular}{ccccccc}
\hline Derslik & Sira Ort. & Sira Top. & SS & U & Z & \multirow{2}{*}{0} \\
\hline Var & 276.48 & 106721 & \multirow{2}{*}{0.742030} & \multirow{2}{*}{0.228} & \\
Yok & 279.85 & 47014 & & \\
\hline
\end{tabular}

Tablo 6'da okulda müzik dersliği olan ve olmayan öğretmenlerin cevapları karşılaştırılmıştır. Bu cevapların karşılaştırılmasında $\mathrm{p}<.05$ düzeyinde anlamlı bir farka rastlanmamıştır. Eşlik çalmaya ilişkin görüşlerin okulda müzik dersliğinin olup olmamasından etkilenmediği söylenilebilir.

Tablo 7

Derslikte Piyano Olması Değişkenine Yönelik Karşılaştırma

\begin{tabular}{ccccccc}
\hline Piyano & Sira Ort. & Sira Top. & SS & U & Z & \multirow{2}{*}{0} \\
\hline Var & 278.22 & 99048 & \multirow{2}{*}{0.485502} & \multirow{2}{*}{0.054} \\
Yok & 278.99 & 55798 & & & \\
\hline
\end{tabular}

Tablo 7‘de yer alan veriler incelendiğinde. derslikte piyano olması veya olmaması değişkeni için $p<.05$ düzeyinde anlamlı bir farklılık oluşmadığı gözlenmiştir. Buna göre ankette verilen cevaplar ve oluşan genel eğilim. ders yapılan ortamda piyano olup olmamasından etkilenmemektedir.

\section{Tablo8}

Mesleki Kıdem Değişkenine Yönelik Karşılaştırma

\begin{tabular}{|c|c|c|c|c|c|c|}
\hline Kıdem & Sira Ort. & SS & $X^{2}$ & sd & $\mathbf{p}$ & Fark \\
\hline $1-5$ yll & 285.10 & & & & & \\
\hline 6-10 yil & 342.62 & & & & & $6-10 / 11.15$ \\
\hline $11-15 \mathrm{yll}$ & 244.83 & 1.36 & 18.87 & 4 & .001 & $6-10 / 15-20$ \\
\hline $15-20$ yıl & 267.77 & & & & & $6-10 / 21$ ve üzeri \\
\hline 21 ve üzeri & 271.70 & & & & & \\
\hline
\end{tabular}

Mesleki kıdem derecesine yönelik ölçümde H testi kullanılmış ve ölçüm sonucu $\mathrm{p}<.05$ düzeyine göre anlamlı bir farkı işaret etmiştir. Sıra ortalaması değeri incelendiğinde oluşan genel eğitimin 6 ila 10 yıl arasında kıdeme sahip müzik öğretmenlerinden yana olduğu anlaşılmaktadır. Dağılım normal olmadığı aynı zamanda varyans eşitliği de sağlanamadığından Dunnett C ile post-hoc ölçümü yapılmıştır. Varyans homojenliği için Levene testi uygulanmış ve sonuç $\mathrm{p}<.05$ düzeyinde manidar bulunduğu için varyans eşitliğinin sağlanamadığı anlaşılmıştır. Bu ölçümde de 6-10 yıl kıdemindeki öğretmenlerin 1-5 yıl hariç diğer kıdem türlerine oranla farklılık gösterdiği anlaşılmıştır. 


\section{Sonuç ve Öneriler}

Elde edilen sonuçlar. piyano ile eşlik çalmanın. piyano ile eşlik yapmayı öğrenmenin. piyano ile eşliği derslerde kullanmanın son derece önemli ve gerekli olduğuna inana bir öğretmen kitlesi olduğuna işaret etmektedir. Araştırmaya katkı veren müzik öğretmenleri gerek eğitiminin verilmesi. gerekse bunun okullarda kullanılması hususunda oldukça önemli düzeyde pozitif bir tepki vermiştir. Öğretmenlerin piyano ile eşliğin önemi ve gerekliliğine inancının yüksek olduğunu söylemek mümkündür. Müzik öğretmenleri gerek ölçeğin genel puan ortalaması. gerekse üç alt başlıktaki puan ortalamaları açısından önemli ölçüde pozitif bir eğilim göstermiştir. İlgili tablolar incelendiğinde eğilimin genel olarak pozitif yönde olduğu anlaşılmaktadır.

Değişkenlere yönelik karşılaştırmalarda ise cinsiyet değişkenine yönelik anlamlı fark bulunmazken. kıdem değişkeni için farka bulunmuştur. Kıdem değişkenine yönelik karşılaştırmada ise anlamlı farka rastlanmış ve bu farkın 6-10 yıllık öğretmenler düzeyinde olduğu gözlenmiştir. Bu durumda önem ve gereklilik algısının 6-10 yıllık öğretmenlerde kısmen daha iyi gerçekleştiği yorumu yapılabilir.

İstatistik bilgi içeren araştırmalarda karşılaştırmalı ölçüm düzeyinde anlamlı fark oluşması. farkı yorumlamak ve buna göre durumu açıklamak açısından daha çok tercih edilen bir durumdur. Fakat bu çalışmada iki önemli değişkende fark bulunmamış olması sonuçlar açısından daha manidardır. Okulda müzik dersliği olması ve derslikte piyano olup olmadığının sorgulandığı iki değişkende anlamlı farka rastlanmamıştır. Bu değişkenler açısından bakıldığında eşliğin önemi ve gerekliliğine yönelik eğilim bu iki değişkenden etkilenmemiştir. Bir müzik dersliğine sahip olmak ve/veya derslikte piyano bulunması müzik öğretmeni için önemli olanaklardır. Fakat çalışma grubundaki öğretmenler. bu değişkene bağlı kalmaksızın. piyanosu veya dersliği olsa da olmasa da eşliğin önemi ve gerekliliği konusunda pozitif eğilim ortaya koymuşlardır.

Yapılan çalışmada elde edilen veriler piyano ile eşliğin önemi ve gerekliliği konusunda müzik öğretmenlerinin kararlılığını da belli ölçüde hatırlatmaktadır. Bu sebeple piyano ile eşlik eğitiminin hem içerik bakımından. hem de müzik öğretmenliği programlarındaki yeri bakımından doğru düşünülmesi önemli bir ihtiyaç olarak düşünülmektedir. İlerleyen zamanlarda bu konuda hizmet içi eğitime gerek kalmaksızın doğru ve yeterli bir eşlik eğitiminin verilmesi de önemli olabilir. Bu kapsamda kendi lisans programında bu becerileri yeterince kazanamamış olduğuna inanan müzik öğretmenlerinin hizmet içi eğitimler yardımıyla bu becerilerini geliştirmelerine olanak verilmesi de önemli bir gelişme olarak düşünülebilir. Piyano müzik eğitiminde diğer tüm çalgılardan ayrılan farklı bir çalgıdır. Dolayısıyla yeri ve işlevsel kullanımı müzik eğitiminin tüm alanlarında önem arz eder. Bu sebeple gerek lisans programındaki yeri ve önemi. gerekse hizmet içi eğitim ihtiyacı gibi konular. eşlik konusunda öne çıkan ve önem kazanan hususlardır.

\section{Kaynakça}

Ak. B. (2009). Verilerin düzenlenmesi ve gösterimi. Ş. Kalaycı, (Ed.), SPSS uygulamalı çok değişkenli istatistik teknikleri (s. 3-42) içinde. Asil Yayın Dağıtım.

Altungül. A. (2019). Eğitim fakülteleri müzik eğitimi anabilim dallarında piyano ve armoni derslerinin eşlik çalma dersine katkısı (Tez No. 549464) [Yüksek Lisans Tezi, Pamukkale Üniversitesi, Eğitim Bilimleri Enstitüsü]. Yükseköğretim Kurulu Tez Merkezi.

Babacan. M. D., \& Gökbudak. Z. S. (2011). Müzik eğitimi anabilim dallarında piyanoda eşlik dersi sürecinde caz armonisinin kullanılabilirliğinin değerlendirilmesi. E-Journal of New World Sciences Academy Fine Arts. 6(1), 93-113. https://dergipark.org.tr/tr/download/article-file/186584

Balc1. A. (2009). Sosyal bilimlerde araştırma yöntem teknik ve ilkeler. Anı Yayıncılık.

Bayırlı. A. U., \& Yıldız. G. (2021). Müzik eğitimi anabilim dallarında görevli piyano eğitimcilerinin artikülasyon tekniklerinin öğretimi ile ilgili görüşleri. Mehmet Akif Ersoy Üniversitesi Ĕgitim Fakültesi Dergisi, 57, 306335. https://dergipark.org.tr/tr/download/article-file/1349297

Bursal. M. (2017). SPSS ile temel veri analizleri. Anı Yayıncılık.

Can. A. (2017). SPSS ile bilimsel araştırma sürecinde veri analizi. Pegem Akademi.

Çevik. D. B., \& Güven. E. (2011). İlköğretim müzik öğretmenlerinin okul şarkılarına piyanoda eşlik yapabilme konusuna ilişkin görüşleri üzerine bir çalışma. Balıkesir Üniversitesi Sosyal Bilimler Enstitüsü Dergisi, 14(25), 86-98. https://dergipark.org.tr/tr/download/article-file/854380

Çokluk. Ö., Şekercioğlu. G., \& Büyüköztürk. Ş. (2014). Sosyal bilimler için çok değişkenli istatistik SPSS ve LISREL uygulamaları. Pegem Akademi.

Demir. E., Saatçioğlu. Ö., \& İmrol. F. (2016). Uluslararası dergilerde yayımlanan eğitim araştırmalarının normallik varsayımları açısından incelenmesi. Current Research in Education, 2(3), 130 - 148. https://www.researchgate.net/publication/312093046_Uluslararasi_Dergilerde_Yayimlanan_Egitim_Aras 
tirmalarinin_Normallik_Varsayimlari_Acisindan_Incelenmesi_Examination_of_Educational_Researches Published in International Journals In Terms of Normalit

Gün, E., \& Öztürk. T. (2018). Piyanoda deşifrenin önemi, tekniği ve geliştirilmesi. Pamukkale Üniversitesi Sosyal Bilimler Enstitüsü Dergisi, 31, 121-128. https://doi.org/10.30794/pausbed.414679

Kalkanoğlu. B. (2020). Piyano eğitiminde sol el: C. Czerny op.718 sol el etütlerinin analizi. Turkish StudiesEducation, 15(3), 1939-1950. http://dx.doi.org/10.29228/TurkishStudies.42789

Kaptanoğlu. E., \& Çanakçı. P. (2015). Türkiye'de vokal müzikte piyano eşlik alanında yapılmış yüksek lisans. doktora ve sanatta yeterlik tezleri. Elektronik Sosyal Bilimler Dergisi (e-sosder), 14(55), 198-206. https://doi.org/10.17755/esosder.20305

Karakaya. İ. (2014). Bilimsel araştırma yöntemleri. A. Tanrı̈ğgn (Ed.), Bilimsel araştırma yöntemleri (s. 57-83) içinde. Anı Yayıncılık.

Kardeş. B., \& Akbulut Demirci, Ş. (2019). Müzik derslerinde eşlik kullanımının müzik öğretmenleri görüşleri doğrultusunda değerlendirilmesi. Atatürk Üniversitesi Güzel Sanatlar Enstitüsü Dergisi, 42, 157 - 172. https://doi.org/10.32547/ataunigsed.500672

Kurtuldu. M. K. (2016). Piyano ile eşliğin önemi ve gerekliliğine yönelik ölçeğin geliştirilmesi. Balıkesir Üniversitesi Sosyal Bilimler Enstitüsü Dergisi, 19(35), 323-344. https://doi.org/10.31795/baunsobed. $\underline{645330}$

Kurtuldu. M. K. (2018). Müzik öğretmeni adaylarının eşlik çalma dersi başarılarının bazı değişkenler yardımıyla incelenmesi. Journal of Social And Humanities Sciences Research (JSHSR), 5(23), 1284-1292. https://pdfs.semanticscholar.org/894c/5f691f490c9afbe7e8b3aee1af3356ced293.pdf

Okan, H., \& Mohan Kömürcü. H. (2020). Konservatuvar öğrencilerinin eşlik dersine ilişkin metaforik yaklaşımlarının farklı değişkenler açısından incelenmesi. YYÜ Eğitim Fakültesi Dergisi, 17(1), 1415-1443. https://doi.org/10.33711/yyuefd.838445

Özalp, U., \& Özdemir, G. (2015). Deşifre eşlik çalımında akor şifrelerinin kullanımı. Pamukkale Üniversitesi Sosyal Bilimler Enstitüsü Dergisi, 22, 47-53. https://dergipark.org.tr/tr/download/article-file/411701

Özdemir, G. (2017). Müzik öğretmeni yetiştiren kurumlarda piyano ile eşlikleme becerileri üzerine sistematik derleme çalışması. Pamukkale Üniversitesi Sosyal Bilimler Enstitüsü Dergisi, 30, 123-132. https://www.journalagent.com/pausbed/pdfs/PAUSBED_2018_30_123_132.pdf

Özelma, Y., \& Çiftçi. E. (2013, Kasım 22-24). Türkiye'de müzik öğretmeni yetiştiren kurumlarda piyanonun eşlik çalgısı olarak kullanılma durumu [Konferans sunumu]. International Symposium on Changes and New Trends in Education, Selçuk Üniversitesi, Konya.

Pala, A., Zahal, O., \& Gürpınar. E. (2016, Eylül 26-28). Müzik ögretmenlerinin ortaokul müzik derslerinde piyanoorg çalgılarını kullanabilme durumları (Malatya ili örneği) [Konferans sunumu]. 2. Uluslararası Müzik ve Dans Kongresi, Muğla.

Sevinç, B. (2017). Survey araştırması yöntemi. K. Böke (Ed.), Sosyal bilimlerde araştırma yöntemleri (s. 245283) içinde. Alfa Yayın Dağıtım.

Sökmen, K. T. (2018). Türkiye'de müzik öğretmenlerinin piyanoda eşlik sorunları ve çözümleri üzerine bir çalışma. Eurasian Journal of Music and Dance, 13, 23-33. https://doi.org/10.31722/konservatuvardergisi. $\underline{491685}$

Taşpınar, M. (2017). Sosyal bilimlerde SPSS uygulamalı nicel veri analizi. Pegem Akademi. 